\title{
SUSTAINABLE DEVELOPMENT SOLUTIONS AND COMPLEX IT MEANS FOR EVALUATION OF WATER POLLUTION PROCESSES
}

\author{
Dalè DZEMYDIENË* \\ Department of Business Technologies and Entrepreneurship, Faculty of Business Management, \\ Vilnius Gediminas Technical University, Sauletekio al. 11, 10223, Vilnius, Lithuania \\ "E-mail: dale.dzemydiene@vgtu.lt
}

\begin{abstract}
The purpose of this research is the developing of decision support system (DSS) by integrating all working information systems (ISS) for wastewater pollution evaluation processes by contributing in achieving the common goal of the Helsinki Convention (HELCOM) for countries to preserve and restore the ecosystems of the Baltic Sea.

Research methodology based on design approach for the development of DSS as a multi-layered system with the multi-componential, interoperable structure of databases (DBs), data warehouses, and IS, which are under the responsibility of different public administration institutions.
\end{abstract}

Findings - presented results on integration of information sources and collaboration workflows help in searching of suitable indicators for revealing the situations of water pollution from wastewater bodies and objects in districts of Lithuania and the effluxes in the Baltic Sea.

Research limitations - the complexity of pollution processes and the multi-layered structure of distributed ISs under different responsibilities identify problems and requirements for adequate DSS working online.

Practical implications - the results will help for influencing the decisions provided for responsible institutions of Lithuania and other members of the HELCOM, responsible for the protection of the marine environment of the Baltic Sea.

Originality/Value intend to assess the sustainability requirements in the wastewater sector, by providing integrated collaboration of ISs.

Keywords: information systems (ISs), decision support system (DSS), sustainable development requirements, evaluation of water pollution.

JEL Classification: Q52, Q25, Q01, O32, O33, Q55.

Conference topic: Digitalization of Business Processes: Trends, Challenges, Solutions.

\section{Introduction}

The main scientific problem aroused in the sustainable development research area is the complexity of assessment of the environmental pollution situations related to the management of water resources and sewage contamination. Developing and advanced countries in the European Union (EU) are faced with the challenges of sustainable development of different importance. Requirements remain for the use of natural resources and for clean environmental issues. Our research is intended to assess the sustainability requirements in the wastewater sector, by developing integrated DSS.

Starting from 1992, when the Sustainable Development Agenda 21 was formulated at the World Summit in Rio de Janeiro (Agenda 21, 1992), the goals for the implementation of requirements of sustainable development became more actual in nowadays economy. New 17 Sustainable Development Goals (SDGs) and 169 targets we found in the Agenda for Sustainable Development of Transforming our World until the 2030 year, which adopted on 25 September 2015 by Heads of States and Governments at a special UN Summit (Agenda 2030, 2015).

The Helsinki Convention (HELCOM) ratified by Lithuania highlights the protection of the marine environment of the Baltic Sea area. Lithuania is a full member of the Organization of the Convention (HELCOM) and this means that the country is committed to contributing to the common goal of the HELCOM countries to preserve and restore the ecosystems of the Baltic Sea. The Baltic Sea Action Plan focuses on reducing the pollution loads of nitrogen and phosphorus compounds, which became the main blame for eutrophication processes in the Baltic Sea. Concentrations 
of such compounds influence the algal blooms and other related processes. The Baltic Sea is divided into seven parts, each with different reduction targets and maximum Baltic Sea pollution per country. The major part of Lithuania's pollution (more than 85\%) comes to the Baltic Proper, the rest to the Gulf of Riga. These Lithuanian commitments were transferred to the Government of the Republic of Lithuania in 2017, February 1 No. 88 of the Water Development Program for 2017-2023, approved by the Resolution 88.

The aim of this research concerns the evaluation possibilities of water contamination processes influencing the quality of Baltic Sea water. Tasks are related to the construction of DSS, which allow to extract data and make decisions about the situations in the water sector.

As the background of such investigations became the proposed previously the water resource management information system (WHMIS), which combines multi-dimensional infrastructure of information support (Dzemydiene \& Maskeliunas, 2011; Dzemydiene, Maskeliūnas, Miliauskas, Naujikienė, \& Dzemydaitè, 2015). The consideration of real-time processes and possibilities to control them from the point of view of the functioning of enterprises is organized by the integration of complex means of IT. For these purposes the retrospective analysis of contamination processes is needful, as well as the evaluation of current situations with the diagnosis has to be performed. The components of decision support information infrastructure are described for aims of assistance in contamination evaluation of wastewaters. The article is devoted to the search for indicators that would allow a more accurate assessment of water pollution problems in the Baltic Sea Region. Research in this field is intended to assess the feasibility of sustainable development requirements in the sewage management sector. The results presented in this paper describe the framework of information infrastructure for evaluation of water resources, allowing the integration of different data warehouses and databases which are distributed by different responsibilities of institutions.

\section{Related works in the area of development the decision support systems for environment protection}

The proposed DSS can work under the unified coherent framework for solving interrelated problems of the application domain in the area of water environment protection. Such DSS started to develop according to the Implementation of the EU Water Framework Directive (2004-2006). The used unified framework includes all components of the European Environment Information and Observation Network responsible for ReportNet, which is the infrastructure for supporting and improving data and information flows (Saarenmaa, Martin, Jensen, Peifer, \& Mclnnes, 2002; DANCEE, 2004). All countries provided data about specific environment data changes. The Geological Survey of Lithuania, Lithuanian Hydro-meteorological Service, Ministry of Environment of the Republic of Lithuania, and Marine Research Centre are such institutions responsible for providing and maintaining such data in Lithuania.

The developed levels of representation of dynamical aspects of observable processes (i.e., monitoring subsystems) are connected with the Water Resources Information Management System (WRIMS) and others which help in realization of communication between data-warehouses (DWs) in multiple objective decision making (DANCEE, 2004; Dzemydiene \& Maskeliunas, 2011; Dzemydiene et al., 2015).

As related works in the area of development of (DSS) can be mentioned some works proposed by (Baltrènas, Januševičius, \& Chlebnikovas, 2017) in the area of air pollution, (Marčiulaitienė, Šerevičienè, Baltrènas, \& Baltrènaite, 2016) in the pollution of Baltic Sea region, and others by (Mysiak, Giupponi, \& Rosato, 2005) in the area of environment protection under the MULINO project for water resources management. The methodology of designing environment DSS is proposed in the work of (Poch, Comas, Rodríguez-Roda, Sànchez-Marrè, \& Cortés, 2004). Some authors have proposed decision support tools for waste management and treatment (den Boer, J., den Boer, E., \& Jager, 2007). Development of Lithuanian districts and regions in accordance with sustainable development requirements and based on risk analysis is provided in (Galinienè \& Dzemydaite, 2012; Dzemydaitė \& Galinienè, 2013) research studies.

The approach of evaluation of the quality of surface water by using GIS and a heavy metal pollution index (HPI) model in a Coal Mining Area of India presented in (Tiwari, De Maio, Singh, \& Mahato, 2015). How the network of pipe replacements influence the water supply network quality is presented in (Van Dijk \& Hendrix, 2016).

Sustainable development requires that the emerging economy accelerates social progress and improves the state of the environment, so that social policies promote sustainable development of the economy, while environmental policies are cost-effective. One of the most important goals of this Sustainable development strategy is to ensure that the growth of the economy does not increase the use of natural resources and do not exceed the limits of environmental pollution (Agenda 2030, 2015).

The research in the area of on-line monitoring networking developments with artificial intelligence properties can help to eliminate such limitations for developing the adaptable DSS in the future.

\section{The context of decisions providing for water protection requirements}

The strategic analysis distinguishes three main areas of sustainable development: environmental quality and natural resources, economic and social areas stated in (Agenda 21, 1992). When analyzing environmental quality solutions, the focus is on these components - air, water, climate change, landscape, and biodiversity. Proper waste management 
is also important for the quality of the environment. Economic development is analyzed in terms of the environmental impact of the main sectors of the economy - transport, industry, energy, agriculture, housing and tourism, social development - employment, poverty, and social exclusion. Social development includes issues of public health, education and science, preservation of cultural identity and identity, and sustainable consumption.

When analyzing the problems of water quality that are of importance to the public, it should be noted that the activities of the population - economy, technology, water resources management make a huge direct impact on the safe use of water resources in terms of both quantity and quality. The demand for water resources depends on the livelihood of the population. Food and its production is an important factor influencing water consumption (see Figure 1).

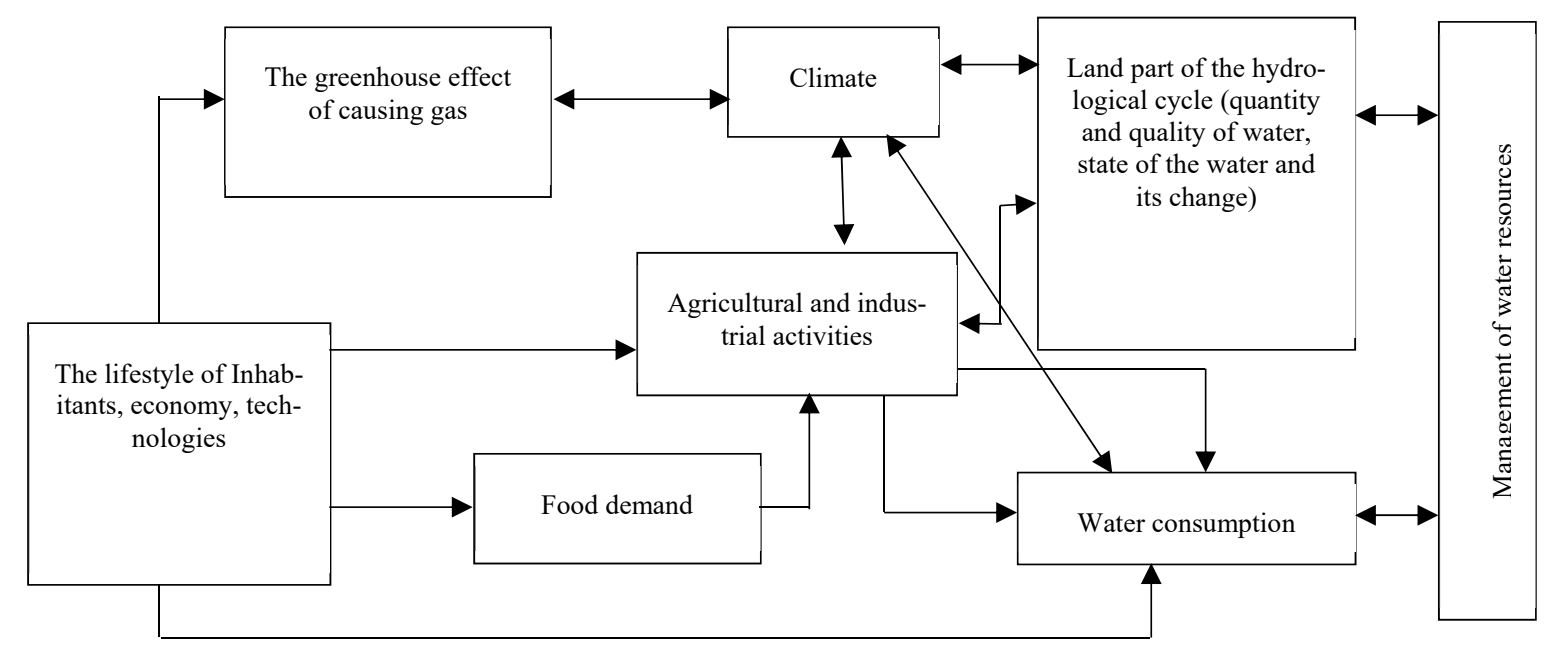

Figure 1. The main factors influencing the economy and population activity affecting freshwater resources and their management (source: Dzemydiene, Maskeliūnas, Dzemydaitè, \& Miliauskas, 2016)

In order to preserve a cleaner environment, high-quality of water resources, it is important to use the all complex means including the state, municipal, private, and EU structural funds for environmental protection effectively (The Article of the Ministry of Environment Protection of Republic of Lithuania, 2016).

\section{The infrastructure of information systems in the wastewater treatment sector}

The collaboration processes of stakeholders at water management and wastewater treatment sector integrate databases, information systems and data warehouses of responsible institutions of EU and Lithuania according to the requirements of EU Water Framework Directive (2004).

The main information flows and collaboration processes of such infrastructure are presented in Figure 2. Denotations used in Figure 2:

- EC - European Commission;

- EEA - European Environmental Agency;

- EPA - Environmental Protection Agency;

- EPD - Environmental Protection Department;

- MoE - Ministry of Environment of the Republic of Lithuania;

- REPD - Regional Environmental Protection Department;

ReportNet - the infrastructure of EIONET for supporting and improving data and information flows developed according to (Implementation of EU Water Framework Directive, 2004).

The structure of the kernel part of the Water Resource Management Information System (WHMIS) was presented in our previously described works (Dzemydiene \& Maskeliunas, 2011; Dzemydienė et al., 2015).

The information system for data from Marine and transitional waters (ISMA) is functioning in a local area network. All data are integrated into one universal ISMA database. ISMA generates EuroWaterNet data and reports following the requirements of Implementation of the EU Water Framework Directive (2004).

The European Environment Information and Observation Network have responsibilities for ReportNet - the infrastructure for supporting and improving data and information flows. All countries provided data about specific environment data changes. The Geological Survey of Lithuania; Lithuanian Hydro-meteorological Service; Ministry of Environment of the Republic of Lithuania; Marine Research Centre are such institutions responsible for providing and maintaining such data in Lithuania. The WR as a water resource management information system combines multidimensional infrastructure of information for decision support. 


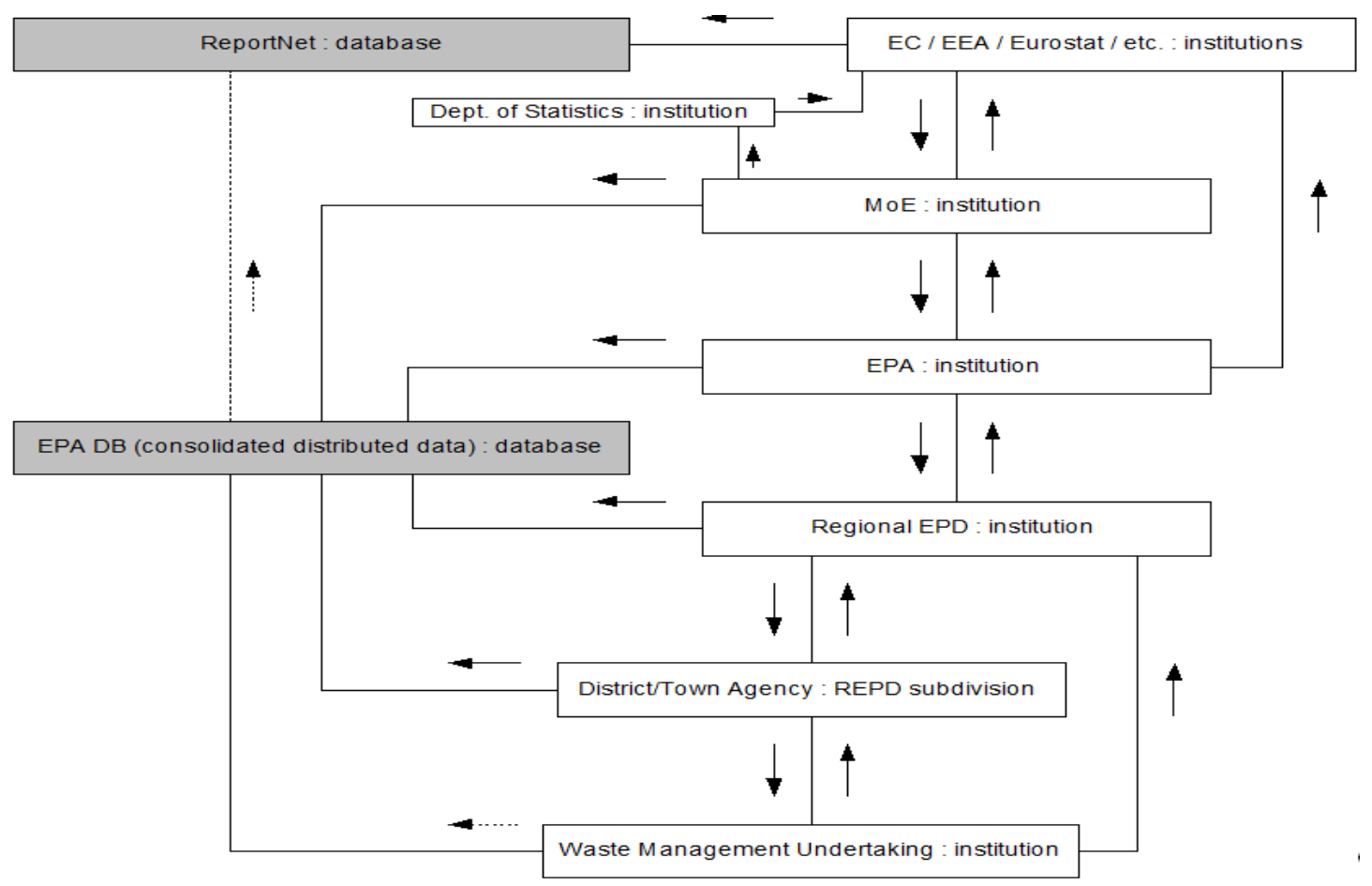

Figure 2. The integration of databases and IS of responsible institutions for water accounting processes (source: Dzemydienè et al., 2016)

\section{Assessment of indicators of surface water in the districts of the Baltic Sea region}

Surface water pollution is the process of discharge of households and industrial wastewater sources thought into the surface water bodies. Water pollution indicators, their appropriate choice, and assessment tools should be taken into account when looking for appropriate pollution accounting methods and their decision-making processes in their decisions. Without the creation and modification of wastewater treatment plants and sewage collection networks, without further measures to reduce agricultural pollution, the pollution level will not be reached to the required level.

Providing sufficient funds for river basin management plans and measures to implement the programs will not improve the status of water bodies. If ground contaminated with chemicals is not wiped out, groundwater status may also deteriorate.

The distribution of farm, domestic and industrial wastewater into surface waters released to clean up to normal wastewater (by thousands $\mathrm{m}^{3}$ ) in the districts of Lithuania during 2013-2017 years shows in Figure 3, according to the official data of the Department of Statistics of Republic of Lithuania (Statistical Department of Lithuania, 2019). By official statistical data, most of the inhabitants of rural settlements not connected to the wastewater management infrastructure. Wastewater is managed by various enterprises, many of them are not able to ensure the quality of services and development. The cost of wastewater treatment services in rural areas is growing faster than consumer income. Many water supply companies are working at a loss, unable to invest in infrastructure development. Water supply and wastewater management infrastructure is inadequate for new technologies. Companies do not have enough funds to maintain the infrastructure that meets their needs. The majority of pollution of water needs bodies is caused by agricultural activities, the negative impact of which is not significantly reduced until now (Resolution No. 1247 of the Government of the Republic of Lithuania, 16.09.2009).

The main objective of the Baltic Sea countries is to achieve a good status of the Baltic Sea environment. 2013 October 3 The Baltic Sea countries Lithuania, Latvia, Estonia, Poland, Germany, Finland, Sweden, Russia, and Denmark approved a Declaration outlining the main environmental problems and goals of the Baltic Sea.

The aims to reduce the pollution of the Baltic Sea according to the countries of the Baltic Convention (by estimations from the Swedish scientists) were based on the Baltic Sea pollution reduction indicators. These indicators allowed to assess the pollution of the Baltic Sea by the countries. For example, according to the calculations, Lithuania up to 2021 should reduce emissions to the Baltic Sea, for example, 8970 tons of nitrogen and 1470 tons of phosphorus in wastewater (The Article of Ministry of Environment Protection of Republic of Lithuania, 2016).

Monitoring of soil contamination in EU associated the Member States can cover about 250,000 potentially polluting operational sources. If current trends in soil contamination across the EU continue, studies indicate that by 2025, the pollution that must be cleaned will increase by $50 \%$. National reports from EU countries show that, for example, heavy metals and mineral oil are the most commonly found soil contamination, while mineral oils and chlorinated hydrocarbons are the most commonly found pollutants in groundwater. 


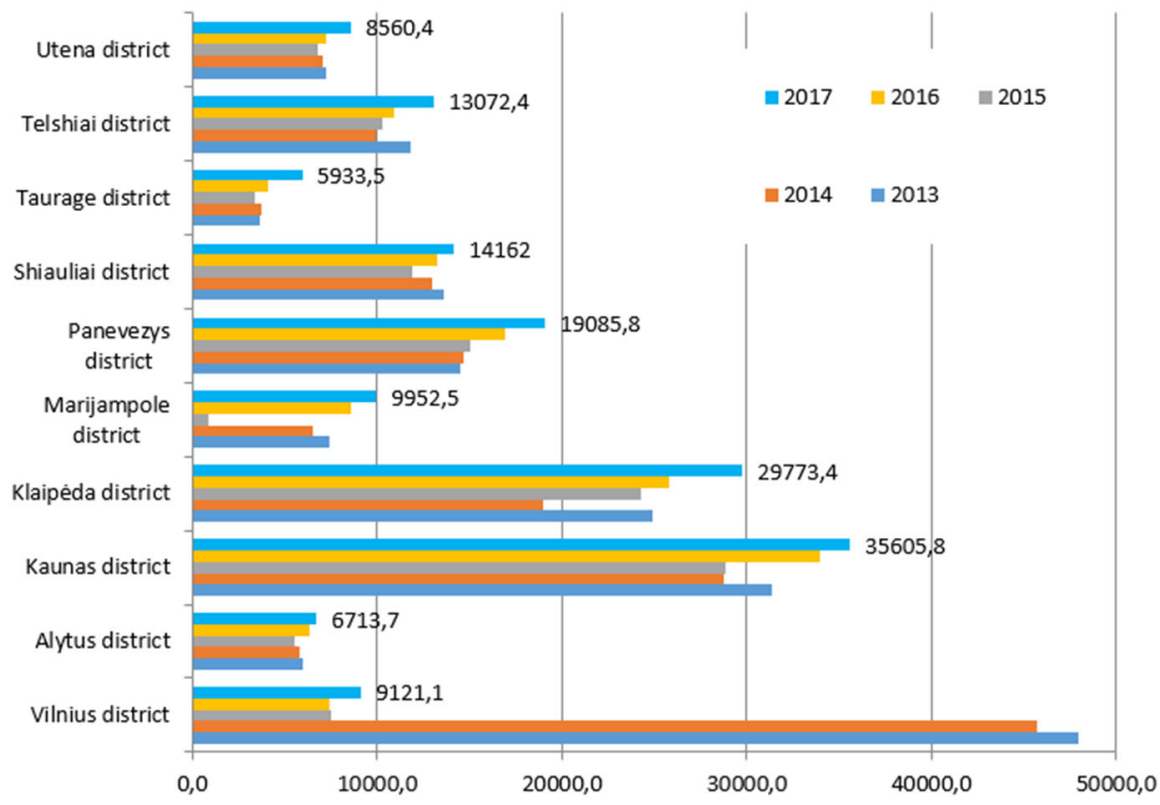

Figure 3. Distribution of amounts of farm, domestic and industrial wastewater cleaned up to normal (in thousands $\mathrm{m}^{3}$ ) released into surface waters by the districts of Lithuania during 2013-2017 years (source: author formation based on the official data of the Statistical Department of Republic of Lithuania, 2019)

The number of pollutants from the territory of Lithuania to the Baltic Sea in tons from 2009 to 2010 noticeably increased (see Figure 4).

The calculation and dynamics of a load of organic substances, nitrogen and phosphorus included in the number of pollutants entering the Baltic Sea from the territory of Lithuania through the territory of the Kaliningrad Region the Nemunas branch Gilija shows in Figure 4. Changes in a load of organic and biogenic materials affect both the extent of pollution and the flow of rivers.

Fluctuations in marine pollution have not led to significant positive changes over a longer period compared to 2005. Contamination with total nitrogen and phosphorus even increased, by the official data analyzed according to official statistics of Lithuania (2013) (see Figure 4).

A considerable part of the cost of cleaning, about $35 \%$ on average, from the public sector budget. It will take decades to clean up existing pollution and some pollution processes are intensifying, although EU countries are obliged to pay sufficiently high pollution taxes.

Water contamination is currently a very important problem for water protection in Lithuania. The results of the state monitoring show that even $51 \%$ of the rivers and $40 \%$ of the lake water bodies do not meet the criteria for good status. All water bodies in the intermediate (Curonian Lagoon) and coastal (Baltic Sea) categories are not in good condition.

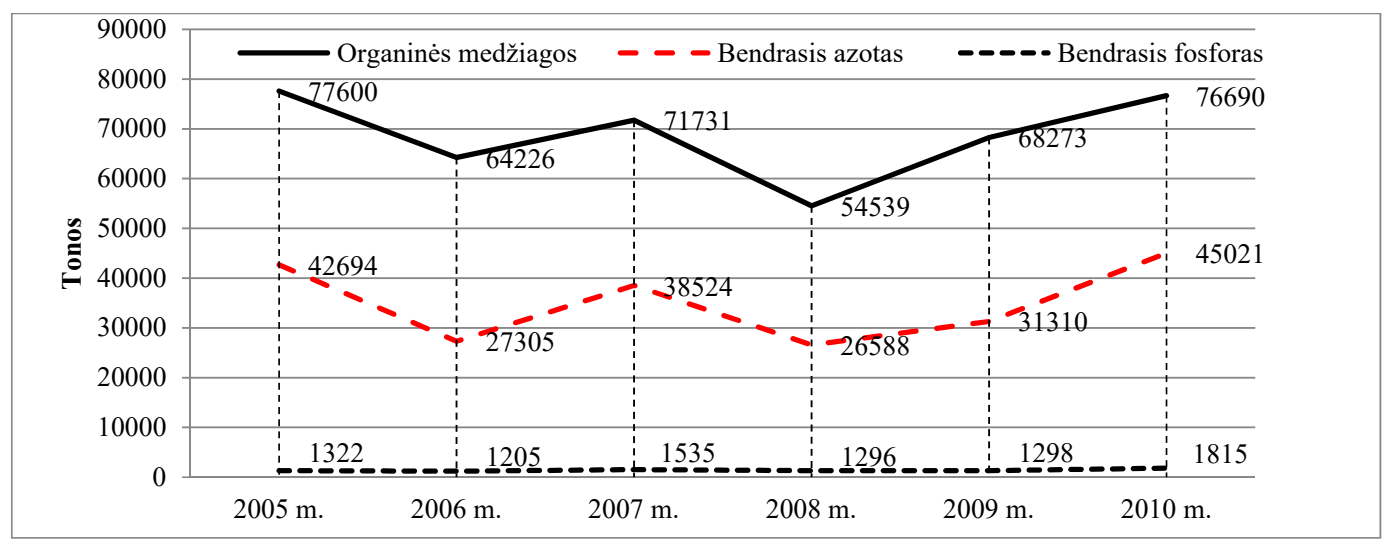

Figure 4. Data on the inflow of pollutants into the Baltic Sea (in tons) during the 2005-2010 year period (source: author formation based on the official data of the Statistical Department of Republic of Lithuania, 2019) 
We would like to note that after the modernization of wastewater treatment plants in the major cities of Lithuania, the impact of point pollution sources (urban or corporate wastewater) on the status of water bodies has significantly decreased. However, this has not happened with pollution from agricultural fields (diffuse sources) - at present, diffuse pollution is the biggest source of water pollution, the importance, and impact of which, as the data show, is increasing. Due to the high diffuse impact of agricultural pollution on good ecological status, over one third of the country's water bodies $-20 \%$ of the Nemunas river basin district (RBD), even $71 \%$ of the Lielupe RBD and $12 \%$ of the surface water bodies in the Venta RBD - do not meet the requirements. This is not surprising since the agricultural area is about $50 \%$ in the Nemunas RBD, 58\% in the Venta RBD and even 65\% in the Lielupe RBD. Spreading pollution in the Nemunas $\mathrm{RBD}$ is the most important factor determining poorer status than intermediate and coastal water bodies.

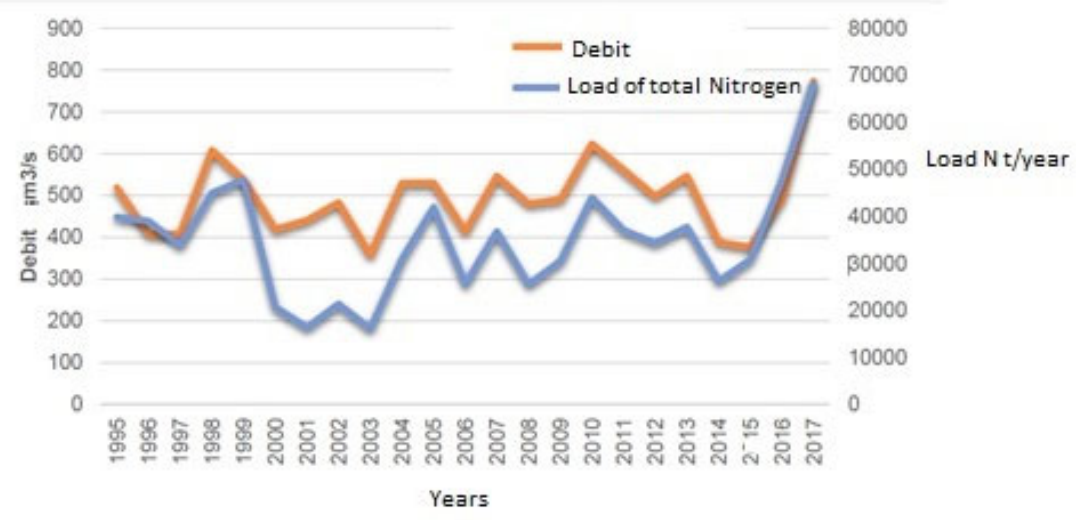

Figure 5. The real load of total nitrogen from the Nemunas to the Curonian Lagoon and the average annual debt of the Nemunas downstream during the period of 1995-2017 (source: author formation based on the official data of the Statistical Department of Republic of Lithuania, 2019)

The data presented in Figure 5 also shows that it is precisely in 2017 that it was an extreme year in terms of aquatic life - at that time, both the water debt and the measured loads were the highest for the entire 23 years period. The Nemunas aquifer was $60 \%$ higher than the average perennial, and the actual load was more than $100 \%$ higher than the average. The load normalization methodology strongly compensated for this variation in wateriness, so normalized loads show a decrease in 2017. However, as shown in Figure 5, real concentrations of nitrogen compounds continued to grow in 2017, just confirming that pollution with nitrogen compounds does not stop growing steadily.

\section{Conclusions}

The presented results show an only fragmental picture of concerning complex problems. The infrastructure of a decision support system for wastewater evaluation and situation diagnosis is complex and multi-dimensional. Works are constantly being carried out. According to the results of the analysis of sewage accounting and pollution indicators, the pollution and impacts of economic actors on pollutants in the Baltic Sea region are not decreasing. Legislation should provide for more effective ways of taxing pollution activities. More attention should be paid to strategic and tactical planning of the environment, operational control of the economic and ecological balance. It is recommended to monitor the impact of pollution, to regularly monitor the work of cleaning systems and to keep track of the ecological balance of indicators.

The European Environment Information and Observation Network have responsibilities for ReportNet - the infrastructure for supporting and improving data and information flows. All countries provided data about specific environment data changes. The Geological Survey of Lithuania; Lithuanian Hydro-meteorological Service; Ministry of Environment of the Republic of Lithuania; Marine Research Centre are such institutions responsible for providing and maintaining such data in Lithuania. Water resource management information system combines multi-dimensional infrastructure of information.

\section{Disclosure statement}

I do not have any competing financial, professional, or personal interests from other parties.

\section{References}

Agenda 2030. (2015). The Agenda for Sustainable Development of Transforming our World until the 2030 year, which adopted on 25 September 2015 by Heads of States and Governments at a special UN Summit.

Agenda 21. (1992). The Sustainable Development Agenda 21 was formulated at the World Summit in Rio de Janeiro. 
Baltrenas, P., Januševičius, T., \& Chlebnikovas, A. (2017). Research into the impact of speed bumps on particulate matter air pollution. Measurement, 100, 62-67. https://doi.org/10.1016/j.measurement.2016.12.042

DANCEE. (2004). Implementation of the EU Water Framework Directive, Lithuania. Danish Co-operation for the Environment in Eastern Europe project.

Den Boer, J., den Boer, E., \& Jager, J. (2007). LCA-IWM: A decision support tool for sustainability assessment of waste management systems. Waste Management, 27(8), 1032-1045. https://doi.org/10.1016/j.wasman.2007.02.022

Dzemydaite, G., \& Galinienè, B. (2013). Evaluation of regional efficiency disparities using efficient frontier analysis. Journal of Economics, 92(4), 21-36.

Dzemydiene, D., \& Maskeliunas, S. (2011). development of multi-componential decision support system in dynamically changing application domain of environment protection, efficient decision support systems - Practice, and challenges from current to future. In Chiang Jao (Ed.), Efficient decision support systems (pp. 405-422). London: IntechOpen Limited.

Dzemydienè, D., Maskeliūnas, S., Dzemydaitè, G., \& Miliauskas, A. (2016). Semi-automatic service provision based on interaction of data warehouses for evaluation of water resources. Informatica, 27(4), 709-722. https://doi.org/10.15388/Informatica.2016.107

Dzemydienė, D., Maskeliūnas, S., Miliauskas, A., Naujikienė, R., \& Dzemydaitė, G. (2015). E-service composition for decision support, based on monitoring of contamination processes and analysis of water resource data. Technological and Economic Development of Economy, 21(6), 869-884. https://doi.org/10.3846/20294913.2015.1069417

European Union. (2004). Implementation of the EU Water Framework Directive. Meeting 2006 deadlines, Technical Notes XVIII: ISMA- Information System for Data from Marine and transitional Waters. Draft. Published 11 November 2004.

Galinienè, B., \& Dzemydaitè, G. (2012). Spatial data envelopment analysis method for the evaluation of regional infrastructure disparities. Social Technologies, 2(2), 390-403.

Government of the Republic of Lithuania. (2009). Resolution No. 1247 of the 16 September, 2009. Retrieved from http://extwprlegs1.fao.org/docs/pdf/lit163657.pdf

Marčiulaitienė, E., Šerevičienė, V., Baltrènas, P., \& Baltrėnaitè, E. (2016). The characteristics of BTEX concentration in various types of environment in the Baltic Sea region, Lithuania. Environmental Science and Pollution Research, 24(4), 4162-4173. https://doi.org/10.1007/s11356-016-8204-x

Mysiak, J., Giupponi, C., \& Rosato, P. (2005). Towards the development of a decision support system for water resource management. Environmental Modelling \& Software, 20(2), 203-214. https://doi.org/10.1016/j.envsoft.2003.12.019

Poch, M., Comas, J., Rodríguez-Roda, I., Sànchez-Marrè, M., \& Cortés, U. (2004). Designing and building real environmental decision support systems. Environmental Modelling \& Software, 19(9), 857-873. https://doi.org/10.1016/j.envsoft.2003.03.007

Saarenmaa, H., Martin, J., Jensen, S., Peifer, H., \& Mclnnes, G. (2002). Development of common tools and shared information infrastructure for the European Environmental Information System (EEA Technical Report No. 83). Retrieved from http://www.eea.europa.eu/publications/technical_report_2002_83

Statistical Department of the Republic of Lithuania. (2019). Portal of Oficial Statistics. Retrieved from https://www.stat.gov.lt/en

Swanson, D. A., Pintér, L., Bregha, F., Volkery, A., \& Jacob, K. (2004). National strategies for sustainable development: Challenges, approaches, and innovations in strategic and co-ordination actions. International Institute for Sustainable Development (IISD), 71. Retrieved from https://www.iisd.org/pdf /2004/measure_nat_strategies_sd.pdf

The Article of the Ministry of Environment Protection of Republic of Lithuania. (2016). New issues for protection of Baltic Sea (in Lithuanian).

Tiwari, A. K., De Maio, M., Singh, P. K., \& Mahato, M. K. (2015). Evaluation of surface water quality by using GIS and a Heavy Metal Pollution Index (HPI) model in a coal mining area, India. Bulletin of Environmental Contamination and Toxicology, 95(3), 304-310. https://doi.org/10.1007/s00128-015-1558-9

Van Dijk, D., \& Hendrix, E. M. T. (2016). Pipe replacement in a water supply network: Coordinated versus uncoordinated replacement and budget effects. Informatica, 27(2), 387-403. https://doi.org/10.15388/Informatica.2016.91 